\title{
FIRST ISOLATION AND MOLECULAR PHYLOGENETIC ANALYSIS OF COXIELLA BURNETII IN LACTATING COWS, IRAQ
}

\author{
H. A. J. GHARBAN \& A. A. YOUSIF \\ Department of Internal and Preventive Veterinary Medicine, \\ College of Veterinary Medicine, University of Baghdad, Baghdad, Iraq
}

\section{Summary}

Gharban, H. A. J. \& A. A. Yousif, 2021. First isolation and molecular phylogenetic analysis of Coxiella burnetii in lactating cows, Iraq. Bulg. J. Vet. Med., 24, No 4, 508-519.

Q fever is an infectious disease of animals and humans, caused by globally distributed C. burnetii. In Iraq, there are no previous studies associated with the detection of the organism in cattle. An overall of 130 lactating cows were submitted to direct collection of milk samples. Initially, the samples of milk were tested using the molecular polymerase chain reaction (PCR) assay targeting three genes (16S rRNA, IS1111a transposase, and $h t p B)$. However, positive results $(18.46 \% ; 24 / 130)$ were detected only with the $16 \mathrm{~s} r R N A$ gene. Concerning risk factors, the highest prevalence of $C$. burnetii was showed in the district of Badra (42.86\%), whereas the lowest - in Al-Numaniyah and Al-Suwaira districts $(\mathrm{P}=0.025)$. There was no significant variation in positivity between the months of sampling period $(\mathrm{P}=0.082)$ and between age groups $(\mathrm{P}=0.076)$. Crossbred cows $(20.69 \%)$ showed a higher positivity than local and pure breeds $(\mathrm{P}=0.043)$. Milk of positive samples $(\mathrm{n}=24)$ was used for cultivation of C. burnetii into specific pathogen free-embryonated chicken eggs (SPF-ECEs). After three passages into SPF-ECEs, contents of yolk sac were collected, subjected for DNA extraction, and retested by PCR assay using the primer of $16 s$ r $R N A$ gene only. Of 24 cultivated milk samples, $12.5 \%$ (3/24) were positive for $C$. burnetii. Finally, the positive local isolates were analysed phylogenetically and reported in NCBI-Genbank under the accession numbers of MN121700.1, MN121701.1, and MN121702.1. In conclusion, this is a unique study as it detected C. burnetii in Iraqi lactating cows, and confirmed that organism was shed actively through milk, suggesting that these animals can play a role as a reservoir for organism with potential risk for transmission of infection from these animals to humans as well as to other animal species.

Key words: cow, Coxiella burnetii, Iraq, isolation, milk, phylogenetic analysis

\section{INTRODUCTION}

Coxiella burnetii is an obligate intracellular bacterial pathogen that infects animals as well as humans resulting in a highly infectious disease named Q fever ("Query fever"). Based on $16 S$ rRNA-encoding gene sequence, $C$. burnetii was moved from Rickettsiales order to Legionellales order, and reclassified under Coxiellaceae family as the only species of Coxiella genus (Kim et al., 2005; Honarmand, 2012). 
Since the first description of disease in 1935 among slaughterhouse workers of Australia, extensive body of knowledge about Coxiella and its infections (Porter et al., 2011) became available. Although domestic ruminants are the main reservoirs, many animals such as ticks, birds, mammals and reptiles have a role in shedding of C. burnetii (Bolanos-Rivero et al., 2017). Large amounts of the organism can be excreted into milk, urine, semen, faeces, vaginal fluids, placenta, and aborted foetuses of diseased animals. Cattle may typically acquire $C$. burnetii by inhalation of infectious droplets or direct exposure to contaminated body fluids (Angelakis \& Raoult, 2011).

One of the most critical points for controlling the spread of Coxiella among animals and from animals to humans is the diagnosis of organism in ruminants (Guatteo et al., 2011). In ruminants, C. burnetii infection is strikingly asymptomatic and occurs at any age (Radostits et al., 2006). Recently, several tools are modified to detect the organism using different samples such as blood, milk, faeces, and tissues (Mohammed et al., 2014). Culture is one of the more reliable diagnostic methods used as a reference standard for detection of microorganisms. In Coxiella, culturing demands growth and requires biosafety level 3 facilities in addition to the cost and impractical use on large samples. Until recently, investigation of $C$. burnetii infection in domestic animals was hampered by the absence of inexpensive and a high sensitive and specific technique (Chosewood \& Wilson, 2009; Porter et al., 2011; Agerholm, 2013). PCR assays have become a more useful tool for detection of $C$. burnetii DNA in acute and chronic infections, and to identify the carrier animals (Fretz et al., 2007; Nicollet \& Valognes, 2007; Muskens et al., 2011). In this era of rapid and inexpensive sequencing, genome sequence comparisons often reveal many polymorphisms that can be used to develop new assays for increased discrimination among samples and for better definition of phylogenetic relatedness (Pereira et al., 2008; Li et al., 2009).

In last decade, Coxiella was reported to be endemic in most countries in the Middle East, and in different animal species (Jaff \& Wilson, 2016; Eldin et al., 2017). In Iraq, no nationwide studies are performed to detect the true prevalence of Coxiella among cattle. Hence, the present study aimed to identify $C$. burnetii in milk samples of lactating cows using the molecular PCR assay, to isolate the organism into the SPF-ECE, and to perform phylogenetic analysis of inoculated positive samples. Association of risk factors (region, period, age, and breed) to the PCRpositivity was also targeted.

\section{MATERIALS AND METHODS}

\section{Ethical approval}

The present study was approved by the College of Veterinary Medicine, University of Baghdad, Iraq. Milk samples were collected and tested without any cost from their owners.

\section{Samples collection}

A total of 130 lactating cows were selected randomly from different areas (AlSuwaira, Al-Aziziyah, Al-Numaniyah, AlKut, Badra and Al-Hai) in Wasit province, Iraq, during November 2018 to May 2019. Fifty $\mathrm{mL}$ of milk were collected from each animal under aseptic conditions into sterile disposable plastic containers. The samples of milk were transported to the laboratory in a cooled plastic ice-box, then divided into 2 parts (one for DNA 
extraction and other for inoculation) using plastic tubes and kept frozen at $-20{ }^{\circ} \mathrm{C}$.

\section{Molecular PCR assay}

All tubes of milk samples were thawed firstly in water bath (Poly-Science, USA) at $37^{\circ} \mathrm{C}$ and shaken vigorously by vortex (Scientific Industries, USA) to ensure that the sample was mixed well. According to manufacturer's instructions (Intron, Korea), the protocol (A) was followed. Nanodrop (Thermo-Scientific, USA) was used to evaluate the purity and concentration of extracted DNA. Targeting three genes; the primers of $16 S r R N A$ [ $\left(\mathrm{F}: 5^{\prime}-\right.$ AGTACGGCCGCAAGGTTAAA-3') and ( $R$ : 5'-CTCCAATC CGGACTACGAGC$\left.3^{\prime}\right)$ ] (NCBI:NR_104916.1), IS1111a transposase, [(F:5'-GATGGGTATCCC AACGCAGT-3') and (R:5'-ACTGCCGG GAACGATGAAAT-3')] (NCBI: MG385669.1), and $h t p B$ [(F:5'-GGCAAT CACCAATAAGG GCCG-3') and (R:5'GCGGGTGATGGTACCACAACA-3')]

(To et al., 1996), were used to amplify $C$. burnetii DNA at 425 bp, 674 bp and 501 bp respectively. PCR mastermix of each primer was prepared in a ready to use AccuPower PCR-PreMix kit (Bioneer, South
Korea) at a final volume of $20 \mu \mathrm{L}$. PCR reaction for each primer was performed in Thermocycler (Bio-Rad, USA) under optimised conditions (Table 1).

Ten $\mu \mathrm{L}$ of each amplimer was analysed in $2 \%$ agarose gel targeting three genes, using 100-2000 bp of DNA marker (Qiagen, Germany). Agarose was stained with $1 \mu \mathrm{g} / \mathrm{mL}$ ethidium bromide (Biotech, Canada), and electrophoresis was carried out $(100 \mathrm{~V}, 80 \mathrm{~mA}, 1 \mathrm{~h})$. Resultant DNA fragments were visualised under a ultraviolet transilluminator (Clinx Science, China)

\section{Isolation of C. burnetii using SPF-ECE}

To isolate $C$. burnetii, the PCR-positive milk sampleswere inoculated into SPFECEs under strict sanitary conditions following previously described protocols (Ho et al., 1995; Cooper, 2011; Kılıç et al., 2016) with some modification. The steps were as followed: $2 \mathrm{~mL}$ of each milk sample were thawed in a water bath at 37 ${ }^{\circ} \mathrm{C}$ and centrifuged at $4000 \mathrm{rpm} / 15 \mathrm{~min}$. Then, $200 \mu \mathrm{L}$ supernatant was inoculated without further preparation into the yolk sac, and incubated for $6-7$ days $\left(37^{\circ} \mathrm{C}\right.$, $60 \%$ humidity) with regular daily ovo-

Table 1. Thermocycler conditions for PCR amplification of targeted genes

\begin{tabular}{|c|c|c|c|c|c|c|c|c|c|}
\hline \multirow{3}{*}{ Step } & \multicolumn{9}{|c|}{ Gene } \\
\hline & \multicolumn{3}{|c|}{$16 S r R N A$} & \multicolumn{3}{|c|}{ IS1111a transposase } & \multicolumn{3}{|c|}{$h t p B$} \\
\hline & Temp. & Time & Cycle & Temp. & Time & $\begin{array}{l}\text { Cy } \\
\text { cle }\end{array}$ & Temp. & Time & Cycle \\
\hline $\begin{array}{l}\text { Initial dena- } \\
\text { turation }\end{array}$ & $95^{\circ} \mathrm{C}$ & $5 \mathrm{~min}$ & 1 & $95^{\circ} \mathrm{C}$ & $2 \min$ & 1 & $95^{\circ} \mathrm{C}$ & $5 \mathrm{~min}$ & 1 \\
\hline $\begin{array}{l}\text { Denatura- } \\
\text { tion }\end{array}$ & $95^{\circ} \mathrm{C}$ & $40 \mathrm{~s}$ & 30 & $94^{\circ} \mathrm{C}$ & $30 \mathrm{~s}$ & 35 & $94^{\circ} \mathrm{C}$ & $1 \mathrm{~min}$ & 30 \\
\hline Annealing & $56^{\circ} \mathrm{C}$ & $40 \mathrm{~s}$ & & $61{ }^{\circ} \mathrm{C}$ & $30 \mathrm{~s}$ & & $56^{\circ} \mathrm{C}$ & $1 \mathrm{~min}$ & \\
\hline Extension & $72^{\circ} \mathrm{C}$ & $1 \mathrm{~min}$ & & $72^{\circ} \mathrm{C}$ & $1 \mathrm{~min}$ & & $72^{\circ} \mathrm{C}$ & $1 \mathrm{~min}$ & \\
\hline $\begin{array}{l}\text { Final } \\
\text { extension }\end{array}$ & $72^{\circ} \mathrm{C}$ & $7 \mathrm{~min}$ & 1 & $72^{\circ} \mathrm{C}$ & $10 \mathrm{~min}$ & 1 & $72^{\circ} \mathrm{C}$ & $5 \mathrm{~min}$ & 1 \\
\hline Hold & $4^{\circ} \mathrm{C}$ & For & ver & $4^{\circ} \mathrm{C}$ & Fore & & $4^{\circ} \mathrm{C}$ & & ever \\
\hline
\end{tabular}


scopy to ensure that all embryos were live. On the seventh day, yolk sac of living embryo was harvested, homogenised with three portions of purified buffered saline (PBS), centrifuged, and $0.5 \mathrm{~mL}$ of supernatants were re-inoculated. After third passage, all SPF-ECEs were examined macroscopically and microscopically to detect and evaluate any abnormalities. Finally, a volume of $0.5 \mathrm{~mL}$ of harvested yolk sac was homogenised in $9.5 \mathrm{~mL}$ PBS, mixed well and subjected for DNA extraction to be tested by PCR.

\section{Phylogenetic analysis}

To document the strains of $C$. burnetii local isolates, the extracted DNAs from positive SPF-ECEs were sent for sequencing in Bioneer Company (South Korea). Multiple Sequence Alignment Program and phylogenetic tree was constructed by MEGA-6 software; whereas the nucleotide sequence data were compared with several $C$. burnetii-16S rRNA sequences from GenBank to determine the homology.

\section{Statistical analysis}

All data were analysed by the computerised programs; Microsoft Office Excel v.16, Paint v. 6.1 and SPSS v. 23. At a level of $\mathrm{P}<0.05$, odds ratio and chi-square $\left(\chi^{2}\right)$ values were calculated to estimate significant prevalence of $C$. burnetii between the groups of each risk factor (George \& Mallery, 2011; Neyeloff et al., 2012).

\section{RESULTS}

Targeting three genes (16S rRNA, IS1111a transposase, and htpB), the PCR assay revealed that $18.46 \%(24 / 130)$ lactating cows were positive for $C$. burnetii infection by the primers of $16 S$ rRNA gene only; whereas, no positive samples were observed with the primers of IS1111a transposase, and htpB genes (Table 2, Fig. 1).

Table 2. Total results of milk samples by PCR assay

\begin{tabular}{llc}
\hline Gene & Positive & Negative \\
\hline I6S rRNA & $\begin{array}{l}24 / 130 \\
(18.46 \%)\end{array}$ & 106 \\
& 0 & 130 \\
$\begin{array}{l}\text { IS1111a } \\
\text { transposase } \\
\text { htpB }\end{array}$ & 0 & 130 \\
\hline * Significant variation in positive results of \\
genes $(\mathrm{P}<0.05)$.
\end{tabular}

Concerning risk factors, the study revealed significant differences for the fac-

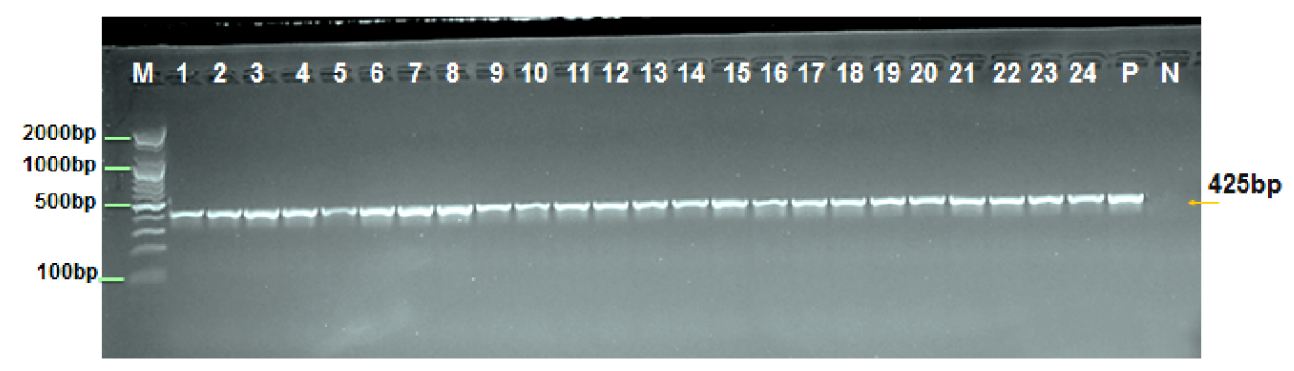

Fig. 1. Agarose gel electrophoresis for the $425 \mathrm{bp}$ PCR product of positive milk samples with C. burnetii. M: DNA marker at 100-2000 bp; Lanes 1-24: Positive samples to $16 S r R N A$; P: Positive control; N: Negative control. 
First isolation and molecular phylogenetic analysis of Coxiella burnetii in lactating cows, Iraq

Table 3. Association of positivity with the risk factors

\begin{tabular}{|c|c|c|c|c|c|}
\hline Group & $\begin{array}{c}\text { Positive/ } \\
\text { Tested }\end{array}$ & $\begin{array}{c}\text { Prevalence } \\
\%\end{array}$ & Risk & $\begin{array}{l}\text { Odds } \\
\text { ratio }\end{array}$ & \\
\hline \multicolumn{6}{|l|}{ Region (district) } \\
\hline $\begin{array}{l}\text { Al-Suwaira } \\
\text { Al-Aziziyah } \\
\text { Al-Numaniyah } \\
\text { Al-Kut } \\
\text { Badra } \\
\text { Al-Hai }\end{array}$ & $\begin{array}{l}1 / 27 \\
4 / 21 \\
0 / 19 \\
7 / 22 \\
9 / 21 \\
3 / 20 \\
\end{array}$ & $\begin{array}{c}3.70 \% \\
19.05 \% \\
0 \% \\
31.82 \% \\
42.86 \% \\
15 \% \\
\end{array}$ & $\begin{array}{l}0.037 \\
0.19 \\
0 \\
0.318 \\
0.429 \\
0.15 \\
\end{array}$ & $\begin{array}{l}0.02 \\
0.24 \\
0 \\
0.47 \\
0.75 \\
0.18 \\
\end{array}$ & $\mathrm{P}=0.025$ \\
\hline \multicolumn{6}{|l|}{ Period (month) } \\
\hline $\begin{array}{l}\text { November } \\
\text { December } \\
\text { January } \\
\text { February } \\
\text { March } \\
\text { April } \\
\text { May }\end{array}$ & $\begin{array}{c}3 / 7 \\
2 / 8 \\
5 / 19 \\
3 / 17 \\
4 / 32 \\
4 / 26 \\
3 / 21 \\
\end{array}$ & $\begin{array}{l}42.86 \% \\
25 \% \\
29.41 \% \\
17.65 \% \\
12.5 \% \\
15.38 \% \\
14.29 \% \\
\end{array}$ & $\begin{array}{l}0.429 \\
0.25 \\
0.26 \\
0.176 \\
0.125 \\
0.154 \\
0.143 \\
\end{array}$ & $\begin{array}{l}0.75 \\
0.33 \\
0.36 \\
0.21 \\
0.14 \\
0.18 \\
0.17 \\
\end{array}$ & $\mathrm{P}=0.082$ \\
\hline \multicolumn{6}{|l|}{ Age (years) } \\
\hline $\begin{array}{l}\leq 3-4 \\
>4-5 \\
>5\end{array}$ & $\begin{array}{c}1 / 11 \\
8 / 51 \\
15 / 68 \\
\end{array}$ & $\begin{array}{r}9.09 \% \\
15.69 \% \\
22.06 \% \\
\end{array}$ & $\begin{array}{l}0.091 \\
0.157 \\
0.221 \\
\end{array}$ & $\begin{array}{l}0.1 \\
0.19 \\
0.28 \\
\end{array}$ & $\mathrm{P}=0.076$ \\
\hline \multicolumn{6}{|l|}{ Breed } \\
\hline $\begin{array}{l}\text { Local } \\
\text { Crossbred } \\
\text { Pure }\end{array}$ & $\begin{array}{c}0 / 5 \\
24 / 116 \\
0 / 9\end{array}$ & $\begin{array}{l}0 \% \\
20.69 \% \\
0 \%\end{array}$ & $\begin{array}{l}0 \\
0.207 \\
0\end{array}$ & $\begin{array}{l}0 \\
0.26 \\
0\end{array}$ & $\mathrm{P}=0.043$ \\
\hline
\end{tabular}

tor region: the highest prevalence of $C$. burnetii was showed in the district of Badra (42.86\%), whereas the lowest prevalence was recorded in Al-Numaniyah and Al-Suwaira districts $(\mathrm{P}=0.025)$. For period factor, a high positivity was seen in November (42.86\%) in comparison to other months, however these differences were not significant $(\mathrm{P}=0.082)$. For age as a factor, though the prevalence of C. burnetii was increased obviously with advanced age, no significant $(\mathrm{P}=0.076)$ correlation was showed between study age groups. Crossbred cows (20.69\%) showed a statistically significantly higher positivity than local and pure breeds $(\mathrm{P}=0.043$; Table 3).
Among inoculated SPF-ECEs, no alterations or lesions were observed among all positive and negative samples with absence of mortalities during the periods of inoculation. Of 24 yolk sac samples subjected to DNA extraction and PCR examination, the results revealed $12.5 \%$ positive samples (Fig. 2).

Genomic DNAs of local isolates were analysed phylogenetically targeting the $16 S$ rRNA gene. Sequencing results of local isolates were named IQ-No.1, IQNo.2, and IQ-No.3 and recorded in NCBI under accession numbers MN121700.1, MN121701.1, and MN121702.1 respectively. Comparative analysis of $16 \mathrm{~S}$ rRNA nucleotide sequences of study strains with 
the $C$. burnetii strains of GenBank database was constructed using the ClustalW Alignment of MEGA-6 software (Fig. 3).

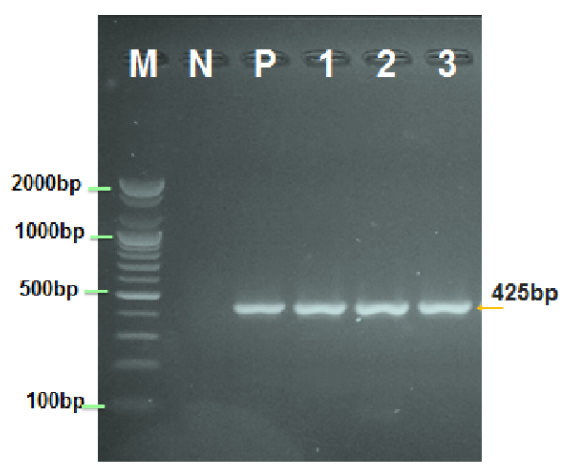

Fig. 2. Agarose gel electrophoresis of the 425 bp PCR product for total positive isolates of C. burnetii. M: DNA marker at 100-2000 bp; P: Positive control; N: Negative control; Lanes 1-3: Total positive samples to $16 \mathrm{~S}$ rRNA which identified by inoculation of previous 24 positive samples into yolk sacs followed by DNA isolation and PCR analysis.

Phylogenetic tree was constructed using Unweighted Pair Group Method with Arithmetic Mean (UPGMA tree) in MEGA-6 software. Comparative identity of study local isolates with the global GenBank isolates reported $99 \%$ of similarity and $0.2-1.2 \%$ of genetic changes (Fig. 4). NCBI-BLAST Homology Sequence showed that there was a significant identity between the local $C$. burnetii strains and $C$. burnetii CB015LAMP (KU215908.1) of Italian strains (Table 4).

\section{DISCUSSION}

Coxiella burnetii is one of the most important pathogens of a worldwide distribution except New Zealand (Reichel et al., 2018). In Iraq, there is a clear lack of information on the role of cattle in shedding of C. burnetii, particularly in lactating cows. Globally, dairy cows are implicated to play a great and important role in transmission of infection for humans through their secretions (indirect) or consumption of raw milk and dairy products (direct). Using PCR assay, $18.46 \%$ of study cows were positives for $16 \mathrm{~S}$ rRNA gene of $C$. burnetii. This finding demonstrates that the prevalence of the pathogen in lactating cows was relatively high, meaning that the disease is endemic in cattle throughout study areas. In comparison to other countries, molecular reports detected that the percentage of bovine $C$. burnetii infection was $4.7 \%$ in Ethiopia (Yewondwosen et al., 2018), 5.35\% in India (Dhaka et al., 2019), 7.43\% in Saudi Arabia (Mohammed et al., 2014), 8.7\% in Hungary (Gyuranecz et al., 2012), 15.9\% in Iran (Esmaeili et al., 2019), 31.54\% in Poland (Szymańska-Czerwińska et al., 2019), 48\% in Turkey (Parin \& Osman,

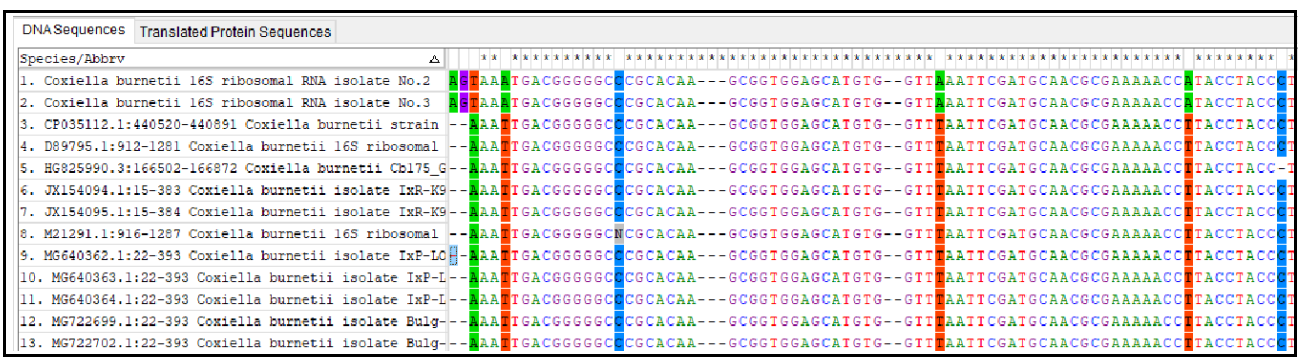

Fig. 3. Multiple sequence alignment analysis in partial $16 S r R N A$ gene of local C. burnetii IQ strains with the strains of NCBI-Blast C. burnetii $16 S r R N A$ gene. 


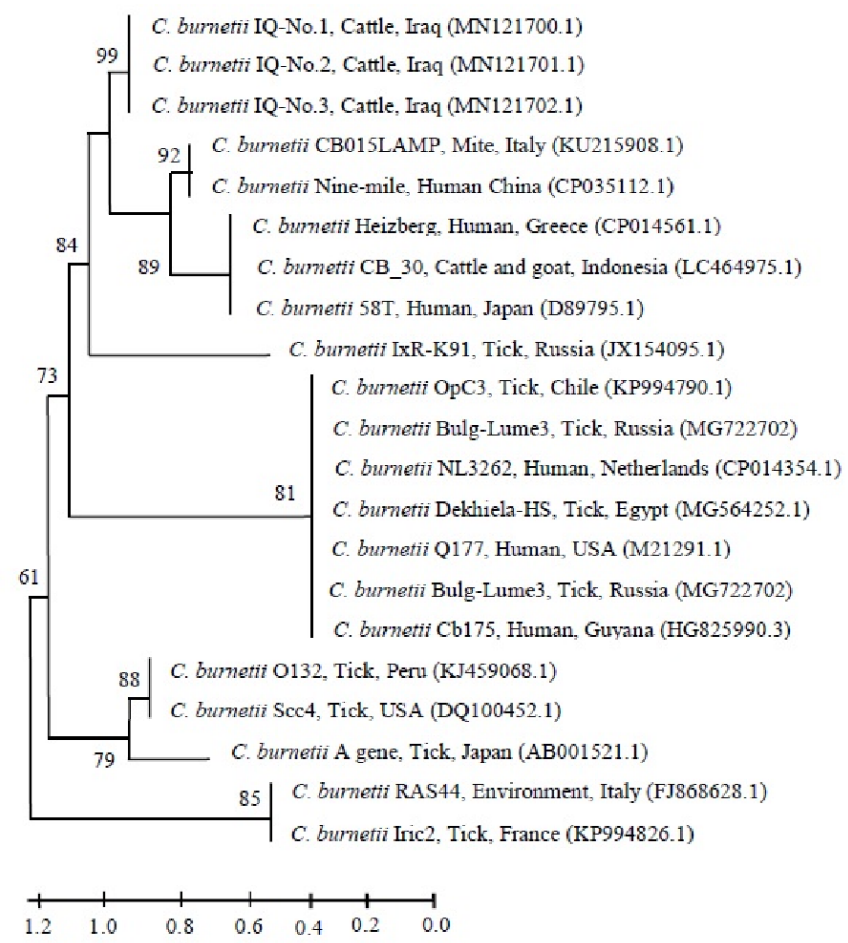

Fig. 4. Phylogenetic tree analysis based on 16S rRNA gene partial sequence in local C. burnetii IQ isolates in comparison to global Genbank-NCBI isolates.

Table 4. NCBI-BLAST Homology Sequence identity between local and NCBI-BLAST C. burnetii isolates

\begin{tabular}{|c|c|c|c|c|}
\hline \multirow{2}{*}{$\begin{array}{l}\text { C. burnetii } \\
\text { study strain }\end{array}$} & \multirow{2}{*}{$\begin{array}{l}\text { GenBank } \\
\text { Accession No. }\end{array}$} & \multicolumn{3}{|c|}{ NCBI-BLAST Homology Sequence Identity (\%) } \\
\hline & & NCBI BLAST & $\begin{array}{l}\text { GenBank } \\
\text { Accession No. }\end{array}$ & $\begin{array}{l}\text { Identity } \\
(\%)\end{array}$ \\
\hline $\begin{array}{l}\text { C. burnetii } \\
\text { IQ-No.1 }\end{array}$ & MN121700.1 & $\begin{array}{l}\text { C. burnetii isolate } \\
\text { CB015LAMP }\end{array}$ & KU215908.1 & $97.50 \%$ \\
\hline $\begin{array}{l}\text { C. burnetii } \\
\text { IQ-No.2 }\end{array}$ & MN121701.1 & $\begin{array}{l}\text { C. burnetii isolate } \\
\text { CB015LAMP }\end{array}$ & KU215908.1 & $97.58 \%$ \\
\hline $\begin{array}{l}\text { C. burnetii } \\
\text { IQ-No.3 }\end{array}$ & MN121702.1 & $\begin{array}{l}\text { C. burnetii isolate } \\
\text { CB015LAMP }\end{array}$ & KU215908.1 & $97.55 \%$ \\
\hline
\end{tabular}

2015), and $94.3 \%$ in United States (Kim et al., 2005). However, the rate of infections in farm animals could be varied considerably between locations, countries, and with time (Radostits et al., 2006). Also, diagnostic method and/or type of tested sample might affect the obtained results. Many studies suggested that the most common route for shedding of Coxiella is milk (Cerf \& Condron, 2006; Guatteo et al., 2007; Rodolakis et al., 2007). Nonetheless, it should be taken into account that the percentage of infected animals may have been underesti- 
mated due to occurrence of intermittent shedding of organisms and the possibility of shedding by several routes (Guatteo et al., 2006; Rodolakis et al., 2007).

The association of risk factors (region, period, age, and breed) to positive prevalence of $C$. burnetii reported significant variations $(\mathrm{P}<0.05)$ in results. Several reports showed that the prevalence rates of $C$. burnetii in animals varied widely depending on the geographical location, climatic conditions, and differences in farming practices or management systems (Psaroulaki et al., 2014; Mobarez et al., 2017). The persistence of animals in a geographically restricted area can reflect on the low prevalence of infection due to the restricted movement of animals which is important in prevention and control of infection (Nusinovici et al., 2013). The recent global warming and climate change has possibly contributed to the widespread distribution of ticks and vector-borne disease as Q fever (Dantas-Torres, 2015). Evidence of age susceptibility to infection showed that the positivity was increased insignificantly with the advanced age. This finding could be interpreted by the facts that animals have more infection in advanced age due to the decrement of immunity, and infected animal remain carrier for all life. The influences of cattle breed on susceptibility to Coxiella infection were discussed in present study. However, the obtained findings could be explained with either the low number of local and purebred subjects selected for examination, high resistance of local breed to infection, and superior management conditions for purebred cattle, or to the potential effect of genetic variation in breed infectivity of cattle.

Isolation of $C$. burnetii can be achieved from a wide range of clinical samples; however, it requires specialised laborato- ries with biosafety level 3, cell culture facilities, and is time consuming. In addition, this organism does not grow easily within most standard tissue cultures, and isolation is not used routinely for diagnosis of Q fever (Dalton et al., 2014; Yewondwosen et al., 2018). Full absence of macroscopic and microscopic lesions and alterations in positive and negative SPFECEs seen in this study might be ascribed to failure of $C$. burnetii to produce lesions or presence of minimal lesions. We suggested that the local strain might have no or low pathogenic action on SPF-ECEs. Also, considerable variations in the ability of Coxiella to create infection might be due to the effect of challenge dose, in addition to the route and period of infection. In this study, the low positive numbers of inoculated SPF-ECEs could be attributed to many reasons such as that the SPF-ECE is not the suitable method for cultivation, presence of certain materials in milk that reduce or prevent the growth of organism in SPF-ECE, and existence of a low number of viable organisms. Omsland et al. (2009) summarised that $C$. burnetii was characterised by inability to propagate under axenic (host cell-free) culture conditions that imposes severe experimental constraints, and suggested a new developed complex medium [Acidified Citrate Cysteine Medium (ACCM)]. Other reasons include failure of the organisms to grow and errors during inoculation, incubation, and harvesting steps. However, successful isolation of C. burnetii in SPFECEs with application of PCR as a confirmative method provided further evidence that the organism is present in raw milk of study cows. These findings indicate that the people as well as animals were exposed efficiently to pathogenic agent that is deemed as one of the most potential agent for bioterrorism due to its 
ability for survival in environment, transmission, and very low infectious dose (Oyston \& Davies, 2011; Brooke et al., 2013).

Phylogenetic analysis and the Homology sequence identity reported that the study local isolates had high similarities to global $C$. burnetii isolates existing in NCBI-Genbank. Based on $16 S$ rRNA gene sequence, phylogenetic analysis has placed Coxiella along with Legionella, Francisella, and Rickettsiella in the Gammaproteobacteria class (McLaughlin et al., 2017). C. burnetii, as the single species within the Coxiella genus, has a particular importance due to its complexity for culturing and restrictions of the agent due to the fact that the collections of this organism are small and rare, making it more important to rely upon existing work in order to facilitate inter-laboratory comparisons among the collections that are available (McQuiston \& Childs, 2002; Hornstra et al., 2011). Such comparisons will lead to a better understanding of the distribution of this pathogen historically, at present, and in the future (Hornstra et al., 2011). Consequently, homology of the sequences obtained from three inoculated C. burnetii strains in this study, is closely related to several strains isolated from cattle, ticks, and mites. Genotypic characterisation of $C$. burnetii strains is vital to trace the source/s of an outbreak, to determine genotypes circulating in a population, and to establish the potential connection between genotypes and virulence of strains (Szymańska-Czerwińska et al., 2019).

\section{CONCLUSION}

For our knowledge, this is the first study in Iraq directed toward detection, isolation and molecular phylogenetic confirmation of local C. burnetii isolates. The findings of present study concluded that cattle livestock in Iraq (particularly in study areas) shedding $C$. burnetii actively in their milk. Diagnostic protocol described here can serve as a bridge between culture, PCR and phylogeny. Nonetheless, the percentage of positives reported in this study does not represent cattle herds in Iraq as the sample size was low, and non-lactating cattle (males, calves, and dry cows) were not involved.

\section{ACKNOWLEDGEMENTS}

The authors are thankful to the Department of Internal and Preventive Veterinary Medicine, College of Veterinary Medicine, University of Baghdad, Baghdad/Iraq, for providing the necessary facilities for this study. The authors did not receive any funds for this study.

\section{REFERENCES}

Agerholm, J. S., 2013. Coxiella burnetii associated reproductive disorders in domestic animals - a critical review. Acta Veterinaria Scandinavica, 55, 1-11.

Angelakis, E. \& D. Raoult, 2011. Emergence of Q fever. Iranian Journal of Public Health, 40, 1-13.

Bolanos-Rivero, M., C. Carranza-Rodríguez, N. F. Rodríguez, C. Gutiérrez \& J. L. Pérez-Arellano, 2017. Detection of Coxiella burnetii DNA in peridomestic and wild animals and ticks in an endemic region (Canary Islands, Spain). Vector-Borne and Zoonotic Diseases, 17, 630-634.

Brooke, R. J., M. E. Kretzschmar, N. T. Mutters \& P. F. Teunis, 2013. Human dose response relation for airborne exposure to Coxiella burnetii. BMC infectious diseases, 13, 1-8.

Cerf, O. \& R. Condron, 2006. Coxiella burnetii and milk pasteurization: An early application of the precautionary princi- 
ple? Epidemiology \& Infection, 134, $946-$ 951.

Chosewood, L. C. \& D. E. Wilson, 2009. Rickettsial agents. In: Biosafety in Microbiological and Biomedical Laboratories, $5^{\text {th }}$ edn, Centers for Disease Control and Prevention, National Institutes of Health, Georgia, pp. 195-199.

Cooper, A. E., 2011. Identification of potential reservoirs of Q fever in Queensland, Australia. Doctoral dissertation, James Cook University, Queensland, Australia, pp. 57-58.

Dalton, H. R., J. Dreier, G. Rink, A. Hecker, K. Janetzko, D. Juhl \& M. Ziemann, 2014. Coxiella burnetii-pathogenic agent of $\mathrm{Q}$ (query) fever. Transfusion Medicine and Hemotherapy, 41, 60-72.

Dantas-Torres, F., 2015. Climate change, biodiversity, ticks and tick-borne diseases: The butterfly effect. International Journal for Parasitology: Parasites and Wildlife, 4, 452-461.

Dhaka, P., S. S. Malik, J. P. Yadav, M. Kumar, A. Baranwal, S. B. Barbuddhe \& D. B. Rawool, 2019. Seroprevalence and molecular detection of coxiellosis among cattle and their human contacts in an organized dairy farm. Journal of Infection and Public Health, 12, 190-194.

Eldin, C., C. Melenotte, O. Mediannikov, E. Ghigo, M. Million, S. Edouard \& D. Raoult, 2017. From Q fever to Coxiella burnetii infection: A paradigm change. Clinical Microbiology Reviews, 30 , 115-190.

Esmaeili, S., A. M. Mobarez, M. Khalili, E. Mostafavi \& P. Moradnejad, 2019. Molecular prevalence of Coxiella burnetii in milk in Iran: A systematic review and meta-analysis. Tropical Animal Health and Production, 51, 1345-1355.

Fretz, R., W. Schaeren, M. Tanner \& A. Baumgartner, 2007. Screening of various foodstuffs for occurrence of Coxiella burnetii in Switzerland. International Journal of Food Microbiology, 116, 414-418.
George, D. \& P. Mallery, 2011. SPSS for Windows step by step: A simple guide and reference 18.0 Update. Edited by Allyn \& Bacon, pp. 35-79.

Guatteo, R., F. Beaudeau, M. Berri, A. Rodolakis, A. Joly \& H. Seegers, 2006. Shedding routes of Coxiella burnetii in dairy cows: implications for detection and control. Veterinary Research, 37, 827833.

Guatteo, R., F. Beaudeau, A. Joly \& H. Seegers, 2007. Assessing the within-herd prevalence of Coxiella burnetii milk-shedder cows using a real-time PCR applied to bulk tank milk. Zoonoses and Public Health, 54, 191-194.

Guatteo, R., H. Seegers, A. F. Taurel, A. Joly \& F. Beaudeau, 2011. Prevalence of Coxiella burnetii infection in domestic ruminants: A critical review. Veterinary Microbiology, 149, 1-16.

Gyuranecz, M., B. Dénes, S. Hornok, P. Kovács, G. Horváth, V. Jurkovich \& N. Vass, 2012. Prevalence of Coxiella burnetii in Hungary: screening of dairy cows, sheep, commercial milk samples, and ticks. Vector-Borne and Zoonotic Diseases, 12, 650-653.

Ho, T., K. K. Htwe, N. Yamasaki, G. Q. Zhang, M. Ogawa, T. Yamaguchi \& K. Hirai, 1995. Isolation of Coxiella burnetii from dairy cattle and ticks, and some characteristics of the isolates in Japan. Microbiology and Immunology, 39, 663-671.

Honarmand, H., 2012. Q fever: An old but still a poorly understood disease. Interdisciplinary Perspectives on Infectious Diseases, 2012, 1-8.

Hornstra, H. M., R. A. Priestley, S. M. Georgia, S. Kachur, D. N. Birdsell, R. Hilsabeck \& P. Keim, 2011. Rapid typing of Coxiella burnetii. PloS One, 6, 1-8.

Jaff, D. \& P. Q. Wilson, 2016. Fever: A Neglected disease in the Middle East. Journal of Health Systems, 16, 12-14. 
Kılıç, A., H. Kalender, O. Koç, Ü. Kılınç, B. Irehan \& M. Berri, 2016. Molecular investigation of Coxiella burnetii infections in aborted sheep in eastern Turkey. Iranian Journal of Veterinary Research, 17, 41-44.

Kim, S. G., E. H. Kim, C. J. Lafferty \& E. Dubovi, 2005. Coxiella burnetii in bulk tank milk samples, United States. Emerging Infectious Diseases, 11, 619-621.

Li, W., D. Raoult \& P. E. Fournier, 2009. Bacterial strain typing in the genomic era. FEMS Microbiology Reviews, 33, 892-916.

McLaughlin, H. P., B. Cherney, J. R. Hakovirta, R. A. Priestley, A. Conley, A. Carter \& D. Sue, 2017. Phylogenetic inference of Coxiella burnetii by $16 \mathrm{~S}$ rRNA gene sequencing. PloS One, 12, 1-18.

McQuiston, J. H. \& J. E. Childs, 2002. Q fever in humans and animals in the United States. Vector Borne and Zoonotic Diseases, 2, 179-191.

Mobarez, A. M., F. B. Amiri \& S. Esmaeili, 2017. Seroprevalence of Q fever among human and animal in Iran; A systematic review and meta-analysis. PLoS Neglected Tropical Diseases, 11, 1-15.

Mohammed, O. B., A. A. Jarelnabi, R. S. Aljumaah, M. A. Alshaikh, A. O. Bakhiet, S. A. Omer \& M. F. Hussein, 2014. Coxiella burnetii, the causative agent of $\mathrm{Q}$ fever in Saudi Arabia: Molecular detection from camel and other domestic livestock. Asian Pacific Journal of Tropical Medicine, 7, 715-719.

Muskens, J., C. Van Maanen \& M. H. Mars, 2011. Dairy cows with metritis: Coxiella burnetii test results in uterine, blood and bulk milk samples. Veterinary Microbiology, 147, 186-189.

Neyeloff, J. L., S.C. Fuchs \& L.B. Moreira, 2012. Meta-analyses and Forest plots using a microsoft excel spreadsheet: Step-bystep guide focusing on descriptive data analysis. BMC Research Notes, 5, 1-6.

Nicollet, P. \& A. Valognes, 2007. Current review of $\mathrm{Q}$ fever diagnosis in animals.
Bulletin de L'Académie Vétérinaire De France, 160, 289-295.

Nusinovici, S., T. Hoch, S. Widgren, A. Joly, A. Lindberg \& F. Beaudeau, 2013. Relative contributions of neighbourhood and animal movements to Coxiella burnetii infection in dairy cattle herds. Geospatial Health, 8, 471-477.

Omsland, A., D. C. Cockrell, D. Howe, E. R. Fischer, K. Virtaneva, D. E. Sturdevant \& R. A. Heinzen, 2009. Host cell-free growth of the Q fever bacterium Coxiella burnetii. Proceedings of the National Academy of Sciences of the United States of America, 106, 4430-4434.

Oyston, P. C. F. \& C. Davies, 2011. Q fever: The neglected biothreat agent. Journal of Medical Microbiology, 60, 9-21.

Parin, U. \& K. A. Osman, 2015. Detection of Coxiella burnetii prevalence in bovine, ovine and caprine herds. Ankara Üniversitesi Veteriner Fakültesi Dergisi, 62, 177-181.

Pereira, F., J. Carneiro \& A. Amorim, 2008. Identification of species with DNA-based technology: Current progress and challenges. Recent Patents on DNA \& Gene Sequences, 2, 187-200.

Porter, S. R., G. Czaplicki, J. Mainil, R. Guattéo \& C. Saegerman, 2011. Q Fever: Current state of knowledge and perspectives of research of a neglected zoonosis. International Journal of Microbiology, 13, 1-22.

Psaroulaki, A., D. Chochlakis, E. Angelakis, I. Ioannou \& Y. Tselentis, 2014. Coxiella burnetii in wildlife and ticks in an endemic area. Transactions of the Royal Society of Tropical Medicine and Hygiene, 108, 625-631.

Radostits, O. M., C. C. Gay, K. W. Hinchcliff \& P. D. Constable, 2006. Q-Fever. In: Veterinary Medicine E-Book: A Textbook of the Diseases of Cattle, Horses, Sheep, Pigs and Goats. Elsevier Health Sciences, Philadelphia, pp. 1468-1469. 
Reichel, M. P., L. C. Wahl \& F. I. Hill, 2018. Review of diagnostic procedures and approaches to infectious causes of reproductive failures of cattle in Australia and New Zealand. Frontiers in Veterinary Science, 5, 1-15.

Rodolakis, A., M. Berri, C. Hechard, C. Caudron, A. Souriau, C. C. Bodier \& J. P. Vadet, 2007. Comparison of Coxiella burnetii shedding in milk of dairy bovine, caprine, and ovine herds. Journal of Dairy Science, 90, 5352-5360.

Szymańska-Czerwińska, M., A. Jodełko, K. Zaręba-Marchewka \& K. Niemczuk, 2019. Shedding and genetic diversity of Coxiella burnetii in Polish dairy cattle. PloS One, 14, 1-16.

To, H., N. Kako, G. Q. Zhang, H. Otsuka, M. Ogawa, O. Ochiai \& M. Akiyama, 1996. Q fever pneumonia in children in Japan. Journal of Clinical Microbiology, 34, 647-651.
Yewondwosen, W., S. Tesfaye, B. Asfaw \& V. Afework, 2018. Seroprevalence and molecular epidemiology of Coxiella burnetii in Northern Ethiopia. Clinical Microbio$\log y, 7,52-64$.

Paper received 12.12.2019; accepted for publication 20.01.2020

\section{Correspondence:}

Hasanain A. J. Gharban

Department of Internal and Preventive Veterinary Medicine,

College of Veterinary Medicine,

University of Baghdad, Baghdad, Iraq,

e-mail: hghirban@uowasit.edu.iq 